\title{
Vandetanib has antineoplastic activity in anaplastic thyroid cancer, in vitro and in vivo
}

\author{
SILVIA MARTINA FERRARI ${ }^{1}$, GUIDO BOCCI ${ }^{1,2}$, TERESA DI DESIDERO $^{1}$, ILARIA RUFFILLI $^{1}$, GIUSY ELIA ${ }^{1}$, \\ FRANCESCA RAGUSA $^{1}$, ANNA FIORAVANTI ${ }^{1}$, PAOLA ORLANDI ${ }^{1}$, SABRINA ROSARIA PAPARO ${ }^{1}$, \\ ARMANDO PATRIZIO $^{1}$, SIMONA PIAGGI ${ }^{3}$, CONCETTINA LA MOTTA ${ }^{4}$, SALVATORE ULISSE ${ }^{5}$, ENKE BALDINI ${ }^{5}$, \\ GABRIELE MATERAZZI $^{6}$, PAOLO MICCOLI ${ }^{6}$, ALESSANDRO ANTONELLI ${ }^{1}$ and POUPAK FALLAHI ${ }^{1}$ \\ ${ }^{1}$ Department of Clinical and Experimental Medicine, School of Medicine, University of Pisa, I-56126 Pisa; \\ ${ }^{2}$ Istituto Toscano Tumori, I-50139 Florence; Departments of ${ }^{3}$ Translational Research and of New Technologies \\ in Medicine and Surgery and ${ }^{4}$ Pharmacy, University of Pisa, I-56126 Pisa; ${ }^{5}$ Department of Surgical Sciences, \\ 'Sapienza' University of Rome, I-00161 Rome; ${ }^{6}$ Department of Surgical, Medical, \\ Molecular Pathology and Critical Area, University of Pisa, I-56124 Pisa, Italy
}

Received November 1, 2017; Accepted February 28, 2018

DOI: $10.3892 /$ or.2018.6305

\begin{abstract}
The antitumor activity of vandetanib [a multiple signal transduction inhibitor including the RET tyrosine kinase, epidermal growth factor receptor (EGFR), vascular endothelial growth factor (VEGF) receptor (VEGFR), ERK and with antiangiogenic activity], in primary anaplastic thyroid cancer (ATC) cells, in the human cell line 8305C [undifferentiated thyroid cancer (TC)] and in an ATC-cell line (AF), was investigated in the present study. Vandetanib ( 1 and $100 \mathrm{nM} ; 1,10,25$ and $50 \mu \mathrm{M}$ ) was tested by WST-1, apoptosis, migration and invasion assays: in primary ATC cells, in the $8305 \mathrm{C}$ continuous cell line, and in AF cells; and in $8305 \mathrm{C}$ cells in CD $n u / n u$ mice. Vandetanib significantly reduced ATC cell proliferation $(\mathrm{P}<0.01$, ANOVA), induced apoptosis dose-dependently ( $\mathrm{P}<0.001$, ANOVA), and inhibited migration $(\mathrm{P}<0.01)$ and invasion $(\mathrm{P}<0.001)$. Furthermore, vandetanib inhibited EGFR, AKT and ERK1/2 phosphorylation and downregulated cyclin D1 in ATC cells. In 8305C and AF cells, vandetanib significantly inhibited the proliferation, inducing also apoptosis. $8305 \mathrm{C}$ cells were injected subcutaneously in CD nu/nu mice and tumor masses became detectable after 30 days. Vandetanib ( $25 \mathrm{mg} / \mathrm{kg} /$ day) significantly inhibited tumor growth and VEGF-A expression and microvessel density in $8305 \mathrm{C}$ tumor tissues. In conclusion, the antitumor
\end{abstract}

Correspondence to: Professor Alessandro Antonelli, Department of Clinical and Experimental Medicine, School of Medicine, University of Pisa, Via Savi 10, I-56126 Pisa, Italy

E-mail: alessandro.antonelli@med.unipi.it

Key words: vandetanib, anaplastic thyroid cancer, primary anaplastic thyroid cancer cells, tyrosine kinase inhibitors, in vitro studies, in vivo studies and antiangiogenic activity of vandetanib is very auspicious in ATC, opening the way to a future clinical evaluation.

\section{Introduction}

Anaplastic thyroid cancer (ATC) represents $\sim 1 \%$ of all thyroid cancer (TC) cases, and is one of the most aggressive human tumors, accounting for $15-40 \%$ of TC-related deaths $(1,2)$. ATC is classified as stage IV (American Joint Committee on Cancer), regardless of tumor size, or presence of lymph node or distant metastases (present in $\sim 80 \%$ of patients at diagnosis) (3-5); median survival is 6 months. The multimodal treatment [including debulking, chemotherapy (doxorubicin, cisplatin, paclitaxel or docetaxel), and hyperfractionated accelerated external beam radiotherapy] is the most effective treatment, with a median survival of 10 months $(6,7)$. Several genetic alterations have been shown in ATC molecular pathways, leading to tumor aggressiveness and progression [p53, BRAF, RAS, RET/PTC, vascular endothelial growth factor (VEGF) receptor (VEGFR)-1, VEGFR-2, epidermal growth factor receptor (EGFR), PDGFR $\alpha$, PDGFR $\beta$, KIT, MET, PIK3Ca, PIK3Cb and PDK1] $(7,8)$. New drugs targeting these molecular alterations have been recently evaluated in ATC (7), but to date no significant improvement in patient survival has been observed.

Vandetanib (ZD6474, Caprelsa ${ }^{\circledR}$ ) is an oral once-daily multi-tyrosine kinase inhibitor (TKI), that inhibits the activation of RET, EGFR, VEGFR-2, VEGFR-3, and slightly VEGFR-1, and has potent antiangiogenic activity (9). Potent antineoplastic action of vandetanib was shown against transplantable medullary thyroid carcinoma (MTC) in nude mice (10). In patients with aggressive MTC, a phase III clinical study showed that vandetanib improved progression-free survival (30.5 vs. 19.3 months in the control group) (11). It was approved by the Food and Drug Administration, and the European Medicines Agency, in 2011, to treat locally advanced or metastatic MTC (12). Vandetanib has also shown promising 
results in aggressive differentiated TC patients not responsive to the usual therapies $(13,14)$. In the present study, we aimed to evaluate the antineoplastic activity of vandetanib in ATC continuous cell lines, and in primary ATC cells, in vitro and in vivo.

\section{Materials and methods}

Drug. The effect of vandetanib (ZD6474, Caprelsa ${ }^{\circledR}$; Aurogene Srl, Rome, Italy; 1 and $100 \mathrm{nM} ; 1,10,25$ and $50 \mu \mathrm{M}$ ) was investigated in vitro in primary ATC cell cultures, in the $8305 \mathrm{C}$ continuous cell line, and AF cells; and in vivo in $8305 \mathrm{C}$ cells in CD nu/nu mice.

Reagents. RPMI-1640 medium was obtained from Gibco (Thermo Fisher Scientific, Inc., Waltham, MA, USA); PCR reagents for quantitative real-time were obtained from Applied Biosystems (Thermo Fisher Scientific, Inc.). The other chemicals and supplements not reported in this section were obtained from Sigma-Aldrich (Merck KGaA, Darmstadt, Germany).

Patient source for thyroid tissue. We obtained surgical thyroid tissue samples from: i) eight ATC patients at surgery; and ii) six healthy subjects who underwent parathyroidectomy. Recognized clinical, laboratory and histological criteria were used to establish the diagnosis (15-17). The absence of thyroglobulin ( $\mathrm{Tg}$ ), thyroperoxidase (TPO), thyroid-stimulating hormone (TSH) receptor, and sodium/iodide symporter (NIS) expression was shown by immunohistochemistry, that was positive for cytokeratin (Fig. 1). DNA extraction and microdissection, and the detection of $B R A F$ mutation were conducted by PCR Single-strand Conformation Polymorphism (by accepted protocols); such as direct DNA sequencing (15-17). All patients and controls agreed to enter the study, which was approved by the local Ethics Committee of the University of Pisa.

Primary ATC cell culture. We prepared ATC cells using protocols published previously (15-17). Cancer tissues were divided in fragments of 1-3 mm, and washed 3-5 times in M-199 media together with streptomycin $(500,000 \mathrm{U} / 1)$, penicillin $(500,000 \mathrm{U} / 1)$ and nystatin $(1,000,000 \mathrm{U} / 1)$. Fragments were suspended in Dulbecco's modified Eagle's medium (DMEM) with penicillin/streptomycin $(50 \mathrm{mg} / \mathrm{l})$, glutamine $(1 \% \mathrm{w} / \mathrm{v})$ and fetal calf serum (FCS) $(20 \% \mathrm{v} / \mathrm{v})$ and then incubated at $37^{\circ} \mathrm{C}$ in $5 \% \mathrm{CO}_{2}$ (all were from Sigma-Aldrich; Merck KGaA).

As soon as the primary culture reached confluence, the cells were transferred into primary tissue culture flasks (Becton-Dickinson Labware, Bedford, MA, USA). To evaluate colony-forming efficacy, cells on their 3rd passage were coated in Methocel ${ }^{\mathrm{TM}}$ (Dow Chemical Co., Milan, Italy) (18). The biggest colonies were spread in tissue-culture flasks (15-17). At the 4th passage, the cells were tested. The absence of Tg, TSH receptor (19), NIS (20), and TPO (21) expression was shown by immunocytochemistry. Focal positivity for cytokeratin was observed by immunocytochemistry (20). DNA fingerprinting demonstrated a pattern similar to the original cancer tissue (15-17).

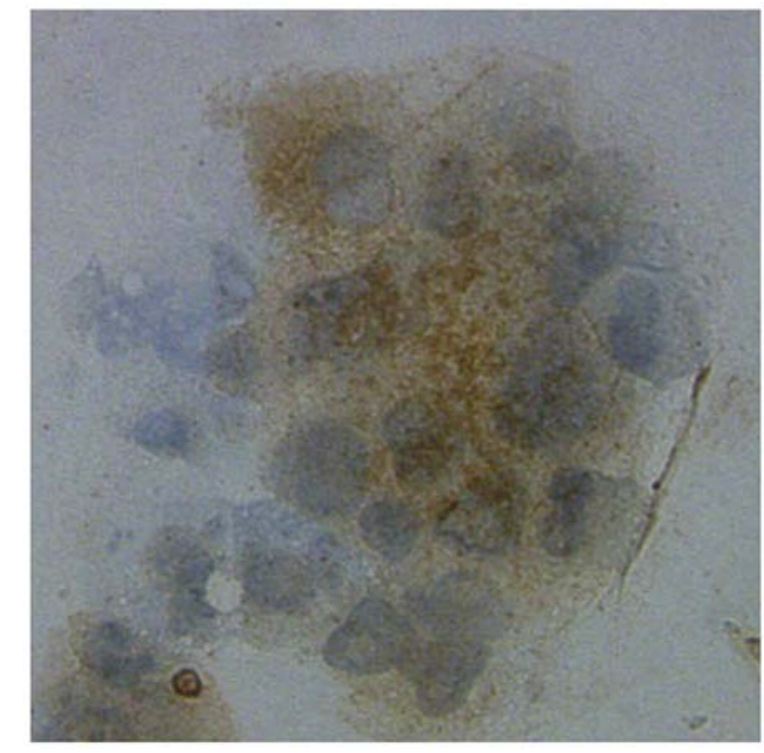

Figure 1. Immunohistochemistry for cytokeratin of anaplastic thyroid cancer (ATC) tissue. The presence of cytokeratin expression is shown in ATC cells (magnification, $\mathrm{x} 400$ ).

Thyroid follicular cell (TFC) culture. TFCs were established as previously reported (22).

AF cells. Among the eight primary ATC cell cultures, one (the AF cell line) grew $>50$ passages, and was also able to grow in $n u / n u$ mice when subcutaneously inoculated.

8305C continuous cell line. 8305C cells (undifferentiated TC cell line, with papillary component; DSMZ, Braunschweig, Germany) were maintained in RPMI-1640 with $15 \%$ fetal bovine serum (FBS) with the addition of $2 \mathrm{mM}$ L-glutamine.

Viability and proliferation assay. In order to investigate cell proliferation, we conducted a WST-1 (Roche Diagnostics, Almere, The Netherlands) $(16,17,22)$. We plated TFC, ATC, AF and $8305 \mathrm{C}$ cells (at 35,000 cells/ml in $100 \mu \mathrm{l} /$ well, of 96 -well plates), and treated them with vandetanib or with vehicle alone for $24 \mathrm{~h}$. To achieve $\mathrm{IC}_{50}$, the cells were treated with a concentration range of vandetanib (in quadruplicate), and $\mathrm{IC}_{50}$ was estimated by linear interpolation. Triplicate experiments were conducted for each cell preparation $(16,17,22)$. The absorbance was estimated at $450 \mathrm{~nm}$ after 1 and $2 \mathrm{~h}$ from the beginning of tetrazolium reaction.

Cell number counting was used, as well, to estimate the proliferation in all the considered cells, as previously reported $(16,17,22)$.

Apoptosis-Hoechst uptake. Firstly, we plated ATC, 8305C and AF cells $(35,000$ cells/ml in $100 \mu \mathrm{l} /$ well; 96-well plates). Thereafter, the cells were treated for $48 \mathrm{~h}$ with vandetanib $\left(37^{\circ} \mathrm{C}, 5 \% \mathrm{CO}_{2}\right)$, and dyed with Hoechst 33342 as previously described (22). The apoptotic cells/total cells x100 ratio (apoptosis index) was evaluated.

Annexin $V$ binding assay for apoptosis. The assay was carried out on cells seeded in Lab-Tek II Chamber Slide System (Nalge 
Nunc International, Penfield, NY, USA), treated with vandetanib for $48 \mathrm{~h}$, as previously reported (22).

Migration and invasion assays. A 96-well Transwell Permeable Support (Corning Life Sciences, Corning, NY, USA) was used to achieve cell migration and invasion, in agreement with the manufacturer's instructions, applying minor modifications $(23,24)$.

To assess intracellular fluorescence, we used a 96-well plate ELISA reader (excitation at $485 \mathrm{~nm}$ and emission at $520 \mathrm{~nm}$ ). For the migration assay cells were incubated for $12 \mathrm{~h}$; for the invasion assay, $24 \mathrm{~h}$. For the invasion experiments, the inserts were coated with a basement membrane extract solution (Trevigen, Gaithersburg, MD, USA) overnight $\left(37^{\circ} \mathrm{C}, 5 \%\right.$ $\mathrm{CO}_{2}$ ), before plating cells. For each assay we constructed a standard curve to transform the fluorescence data obtained to the number of invasive or migrated cells. All the data were analyzed by StatView version 5.0 (SAS Institute, Inc., Cary, NC, USA).

\section{ELISA tests in ATC cells}

Phospho-EGFR inhibition cell-based assay. ATC cells $\left(5 \times 10^{4}\right.$ cells/well) were plated in $1 \%$ FBS medium for $24 \mathrm{~h}$, and then treated for $72 \mathrm{~h}$ with vandetanib at a concentration similar to the experimental $\mathrm{IC}_{50}$ of cell proliferation $(25 \mu \mathrm{M}$ for ATC), and with a higher $(50 \mu \mathrm{M})$, or with a lower $(1 \mu \mathrm{M})$ concentration of vandetanib, or with vehicle. We collected cell lysates as previously reported (25) and we assayed them with PathScan phospo-EGFR (Tyr1173) and total EGFR sandwich ELISA kits (Cell Signaling Technology, Inc., Danvers, MA, USA). Optical density (OD) was estimated at $450 \mathrm{~nm}$.

AKT (pThr308), or ERK1/2 (pTpY185/187). ATC cells $\left(5 \times 10^{4}\right.$ cells/well) were exposed for $72 \mathrm{~h}$ to vandetanib and subsequently lysed (25), and tested for human AKT or ERK1/2 phosphorylation by the PhosphoDetect AKT (pThr308) or by PhosphoDetect ERK1/2 (pThr185/pTyr187) ELISA kits (Calbiochem; EMD Millipore, Billerica, MA, USA). Data were normalized by total protein AKT, or ERK1/2 concentrations evaluated by AKT, or ERK1/2 ELISA kits, respectively. $\mathrm{OD}$ was estimated at $450 \mathrm{~nm}$.

Cyclin D1 protein expression. The ATC cells were exposed for $72 \mathrm{~h}$ to vandetanib at the above considered concentrations or to vehicle, in order to evaluate the vandetanib-modulated expression of the protein cyclin D1. Cyclin D1 protein amount was measured by lysing cells with (ice-cold 1X) lysis buffer $(0.5 \mathrm{ml})$, as previously reported (25). Lysates were gathered and then sonicated on ice (for $10 \mathrm{sec}$ ). Subsequently, the samples were microcentrifuged at $4^{\circ} \mathrm{C}$ for $10 \mathrm{~min}$ and the supernatant was gathered. Cyclin D1 was measured in cancer cell lysates by the human ELISA kit (Uscn Life Sciences, Inc., Wuhan, China). OD was measured at $450 \mathrm{~nm}$, and the obtained data were reported as cyclin D1 $\mathrm{ng} / \mathrm{mg}$ of total protein.

\section{In vivo studies}

Animals and treatment. Six-week-old CD nu/nu male mice weighing 20-25 g, supplied by Envigo (Milan, Italy), were housed in microisolator cages on vented racks and manipulated using aseptic techniques and were allowed unrestricted access to sterile food and water. We proceeded according to the protocol approved by the Academic Organization Responsible for Animal Welfare [Organismo Preposto per il Benessere Animale (OPBA)] at the University of Pisa, in agreement with the Italian law D.lgs. 26/2014, and by the Italian Ministry of Health (authorization no. 613/2015-PR). In order to obtain statistically meaningful results, each experiment was conducted with the minimum necessary number of mice. In each mouse we inoculated, subcutaneously, $2 \times 10^{6} \pm 5 \%$ viable $8305 \mathrm{C}$ cells, on day 0 . Animal weights were monitored, and tumor volume $\left(\mathrm{mm}^{3}\right)$ was defined as: [(w1 x w1 x w2) x $\left.(\pi / 6)\right]$, where w1 refers to the smallest tumor diameter $(\mathrm{mm})$, whereas $\mathrm{w} 2$ to the largest one. We started the treatment $(n=5$ mice/group) after 30 days from cell inoculation, when the mean volume was $\sim 100 \mathrm{~mm}^{3}$. All mice were randomized just before initiation of treatment. Control mice received vehicle alone, or 25 or $12.5 \mathrm{mg} / \mathrm{kg} /$ day of vandetanib, injected intraperitoneally (i.p.) for 29 days. An anesthetic overdose of urethan was used to sacrifice mice, and the tumors were then excised and measured.

Microvessel density in the cancer tissue, and immunohistochemistry. Cancer tissues from the three treatment groups were weighed, and then fixed in formalin and subsequently embedded in paraffin. The sections $(5 \mu \mathrm{m})$ were stained with hematoxylin and eosin, and immunostaining was conducted as previously described (23). An anti-VEGF rabbit polyclonal antibody (diluted at 1:50; cat. no. sc-152; Santa Cruz Biotechnology, Inc., Santa Cruz, CA, USA) was used to estimate VEGF expression, as the percentage of positive cells in $~ 1,000$ tumor cells. Anti-FVIII polyclonal antibody (cat. no. 760-2642; Ventana Medical Systems, Inc.:Roche Group, Tucson, AZ, USA) was used to determine microvascular count (MVC), as previously described (23).

Statistical analysis. For normally distributed variables, the values are expressed as mean $( \pm \mathrm{SD})$, or as median (and interquartile range). Experiments were conducted thrice with ATC from each subject, and here we report the mean in the eight samples obtained by different donors (for TFC and ATC). One-way ANOVA, or Mann-Whitney U or Kruskal-Wallis test, were used to compare mean group values for normally distributed variables. $\chi^{2}$ test was applied to compare proportions. Post hoc comparisons on normally distributed variables were conducted by Bonferroni-Dunn test. Apoptosis results were analyzed by one-way ANOVA with Newman-Keuls multiple comparisons test. All the data were analyzed by StatView version 5.0 (SAS Institute, Inc.).

\section{Results}

In vitro studies in primary cell cultures

Cell proliferation. Vandetanib significantly reduced ATC cell proliferation vs. the control, at 1 and $2 \mathrm{~h}(\mathrm{P}<0.01$, by ANOVA, for both) (Fig. 2A). Cell counting confirmed these results: after $1 \mathrm{~h}$, the cell number was $12,120 \pm 680 / 100 \mu \mathrm{l} /$ well in the ATC control group; 11,998 \pm 710 (99\%) with vandetanib $1 \mathrm{nM} ; 11,635 \pm 780$ (96\%) with vandetanib $100 \mathrm{nM}$; $10,787 \pm 690(89 \%)$ with vandetanib $1 \mu \mathrm{M} ; 9,332 \pm 710(77 \%)$ with vandetanib $10 \mu \mathrm{M} ; 8,610 \pm 580(71 \%)$ with vandetanib $25 \mu \mathrm{M}$; and 3,878 $490(32 \%)$ with vandetanib $50 \mu \mathrm{M}(\mathrm{P}<0.01$, 
A

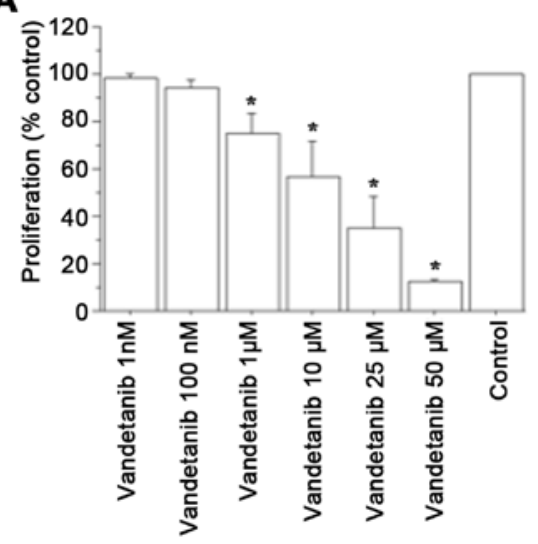

C

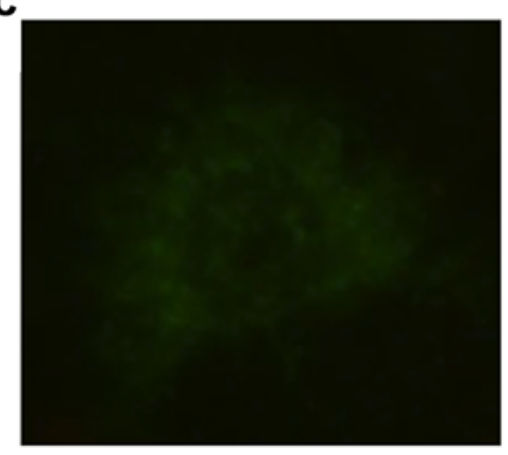

B

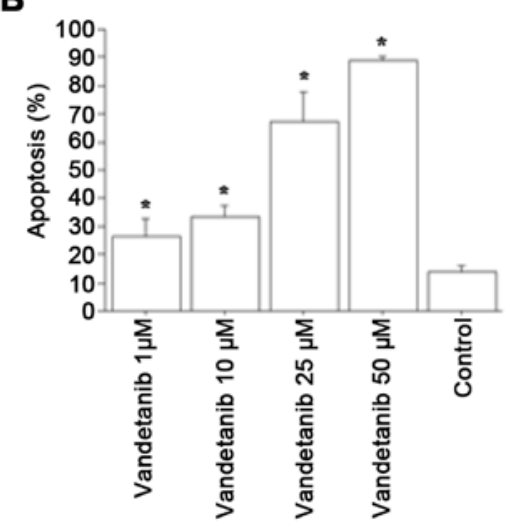

D

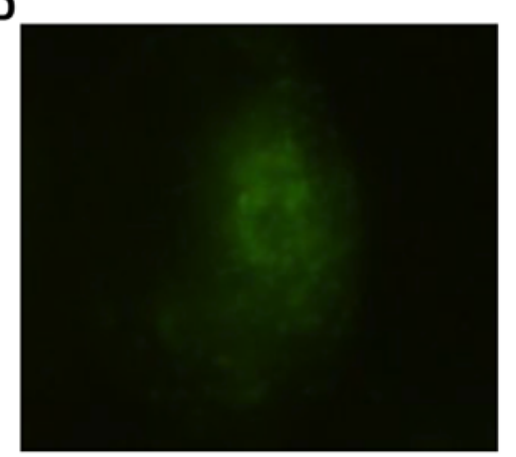

Figure 2. Proliferation (WST-1), and apoptosis assays in primary human anaplastic thyroid cancer (ATC) cells. (A) WST-1 in ATC cells treated with vandetanib for $24 \mathrm{~h}$. Vandetanib significantly reduced ATC cell proliferation vs. control. Bars represent mean $( \pm \mathrm{SD})$. * $\mathrm{P}<0.05$ vs. control with Bonferroni-Dunn test. (B) ATC cell apoptosis after treatment with vandetanib for $48 \mathrm{~h}$. Apoptosis index was determined by Hoechst staining. Vandetanib dose-dependently induced the percentage of apoptotic cells. Data are presented as mean $( \pm \mathrm{SD})(\mathrm{n}=8)$, and were analyzed by one-way ANOVA (with Newman-Keuls multiple comparisons test, and with a linear trend test) (" $\mathrm{P}<0.001$ vs. control). (C and D) Representative images of the Annexin V binding assay in control and treated ATC cells (with vandetanib $50 \mu \mathrm{M})$, respectively.

ANOVA); after $2 \mathrm{~h}$, cell number was $18,950 \pm 910 / 100 \mu \mathrm{l} /$ well; $18,382 \pm 920(97 \%)$ with vandetanib $1 \mathrm{nM} ; 17,623 \pm 990(93 \%)$ with vandetanib $100 \mathrm{nM} ; 14,592 \pm 1,010$ (77\%) with vandetanib $1 \mu \mathrm{M} ; 10,423 \pm 1,180(55 \%)$ with vandetanib $10 \mu \mathrm{M}$; $6,443 \pm 1,190(34 \%)$ with vandetanib $25 \mu \mathrm{M}$; and 2,274 \pm 750 (12\%) with vandetanib $50 \mu \mathrm{M}$; (P<0.01, ANOVA). The $\mathrm{IC}_{50}$ value, obtained with linear interpolation, was $13 \pm 2.9 \mu \mathrm{M}$ for vandetanib.

The results of WST-1 assay in TFC cells with vandetanib showed a slight but significant reduction in proliferation with respect to the control both at $1 \mathrm{~h}(\mathrm{P}<0.01$, ANOVA) with vandetanib $10 \mu \mathrm{M}$ (94\% vs. control), $25 \mu \mathrm{M}$ (87\% vs. control), and $50 \mu \mathrm{M}(81 \%$ vs. control $)$, and at $2 \mathrm{~h}(\mathrm{P}<0.01$, for both, ANOVA) with vandetanib $10 \mu \mathrm{M}$ (87\% vs. control), $25 \mu \mathrm{M}$ (81\% vs. control), and $50 \mu \mathrm{M}$ (76\% vs. control). Cell counting supported the previously reported results: after $1 \mathrm{~h}$, the cell number was $11,290 \pm 730 / 100 \mu \mathrm{l} /$ well in the TFC control; $10,612 \pm 1,080(94 \%)$ with vandetanib $10 \mu \mathrm{M} ; 9,822 \pm 940(87 \%)$ with vandetanib $25 \mu \mathrm{M}$; and 9,145 $\pm 880(81 \%)$ with vandetanib $50 \mu \mathrm{M}$; $(\mathrm{P}<0.01$, ANOVA); after $2 \mathrm{~h}$, the cell number was $17,950 \pm 910 / 100 \mu \mathrm{l} /$ well; $15,615 \pm 1,090$ (87\%) with vandetanib $10 \mu \mathrm{M} ; 14,540 \pm 950(81 \%)$ with vandetanib $25 \mu \mathrm{M}$; and $13,640 \pm 890$ (76\%) with vandetanib $50 \mu \mathrm{M}(\mathrm{P}<0.01$, ANOVA)

Proliferation and BRAF. Three considered ATCs had ${ }^{\mathrm{V} 600 \mathrm{E}} B R A F$ mutation, while RET/PTC1 and RET/PTC3, $\mathrm{H}-\mathrm{RAS}$ or N-RAS mutations were not reported in primary
ATC cells by real-time PCR. Proliferation was inhibited similarly in ATC from cancers with or without ${ }^{\mathrm{V} 600 \mathrm{E}} B R A F$ mutation (data not shown).

Apoptosis. Vandetanib increased the number of apoptotic ATC cells dose-dependently ( $\mathrm{P}<0.001$; by ANOVA; Fig. 2B). The Annexin $\mathrm{V}$ assay corroborated these results (Fig. 2C and D).

Migration and invasion. The effect of vandetanib on migration and invasion was evaluated in ATC cells showing a reduction in both migration (Fig. 3A) and invasion (Fig. 3B).

EGFR inhibition in ATC cells by vandetanib. Vandetanib significantly reduced the phosphorylated (p)EGFR/total EGFR ratio in the ATC cell lysates in a dose-dependent manner (Fig. 4A).

Inhibition of AKT or ERK1/2 phosphorylation in ATC cells by vandetanib. Vandetanib significantly reduced the pAKT/total AKT and pERK1/2/total ERK1/2 protein ratios in the ATC cells (Fig. 4B and C).

Vandetanib decreases cyclin D1 protein levels in ATC cells. Lower cyclin D1 concentrations were detected in ATC cells treated with vandetanib vs. those treated with vehicle, and vandetanib inhibited cyclin Dl gene expression in a dose-dependent manner ( $\mathrm{P}<0.05$; Fig. 4D). 
A

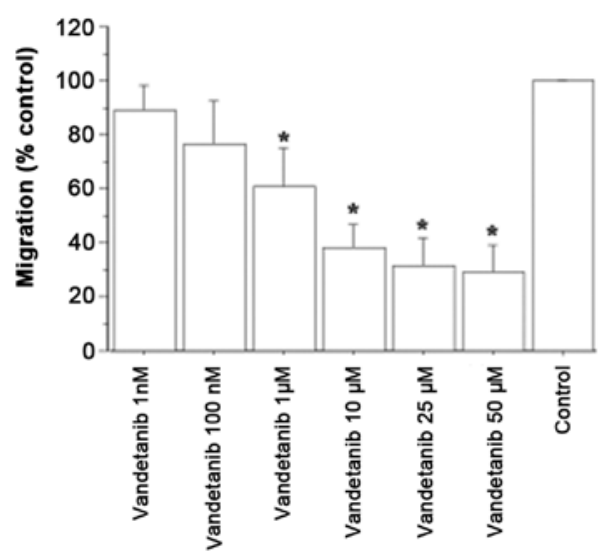

\begin{tabular}{|c|c|c|c|c|}
\hline & Control & Vandetanib $10 \mu \mathrm{M}$ & Vandetanib $25 \mu \mathrm{M}$ & Vandetanib $50 \mu \mathrm{M}$ \\
\hline $\begin{array}{l}\text { Proliferation at } 12 \mathrm{~h} \\
\text { [\% control (mean)] }\end{array}$ & $100 \%$ & $49 \%$ & $41 \%$ & $25 \%$ \\
\hline $\begin{array}{l}\text { Migration at } 12 \mathrm{~h} \\
{[\% \text { control (mean) }]}\end{array}$ & $100 \%$ & $38 \%$ & $32 \%$ & $28 \%$ \\
\hline
\end{tabular}

B

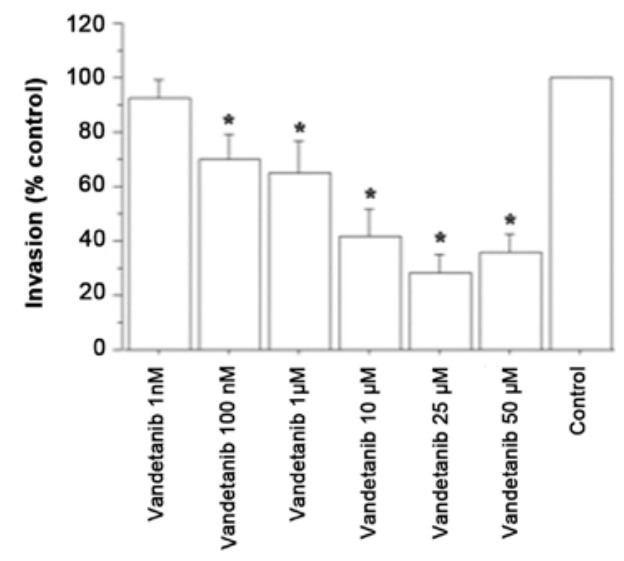

\begin{tabular}{|l|c|c|c|c|}
\hline & Control & Vandetanib $10 \mu \mathrm{M}$ & Vandetanib $25 \mu \mathrm{M}$ & Vandetanib 50 $\mu \mathrm{M}$ \\
\hline $\begin{array}{l}\text { Proliferation at } 24 \mathrm{~h} \\
{[\% \text { control (mean)] }}\end{array}$ & $100 \%$ & $55 \%$ & $34 \%$ & $12 \%$ \\
\hline $\begin{array}{l}\text { Invasion at } 24 \mathrm{~h} \\
{[\% \text { control (mean)] }}\end{array}$ & $100 \%$ & $41 \%$ & $29 \%$ & $37 \%$ \\
\hline
\end{tabular}

Figure 3. Migration and invasion tests in anaplastic thyroid cancer (ATC) cells. ATC cells were incubated for (A) $12 \mathrm{~h}$ for migration and (B) $24 \mathrm{~h}$ for invasion. For comparison, the inhibition of proliferation (at $12 \mathrm{~h}$ ) (\% with respect to control) and the inhibition of migration are reported in the Table in (A), and the inhibition of proliferation (at $24 \mathrm{~h})\left(\%\right.$ with respect to control) and the inhibition of invasion are shown in (B). Bars represent the mean ( \pm SD). ${ }^{*} \mathrm{P}<0.05$ vs. control (control $=$ medium + FCS $10 \%$ ) by Newman-Keuls test.

Studies in vitro in AF and 8305 C cells. Vandetanib demonstrated a dose-dependent antiproliferative activity in the $8305 \mathrm{C}$ cell line ( $\mathrm{IC}_{50}$ of $\left.9.6 \pm 3.4 \mu \mathrm{M}\right)$ (Fig. $\left.5 \mathrm{~A}\right)$, and in $\mathrm{AF}$ cells $\left(\mathrm{IC}_{50}\right.$ of $4.7 \pm 1.8 \mu \mathrm{M}$ ) (Fig. 5B). Vandetanib dose-dependently induced the apoptosis of the $8305 \mathrm{C}$ cells: apoptotic cells were $16.8 \%$ with vandetanib $10 \mu \mathrm{M}$, and 20 and $33.2 \%$ with vandetanib 25 and $50 \mu \mathrm{M}$, respectively ( $\mathrm{P}<0.001$; by ANOVA; Fig. 5C). In AF cells, vandetanib dose-dependently increased apoptosis: apoptotic cells were $19.9 \%$ with vandetanib $10 \mu \mathrm{M}$, and 22.7 and $27.8 \%$ with vandetanib 25 and $50 \mu \mathrm{M}$, respectively ( $\mathrm{P}<0.001$; by ANOVA; Fig. 5D).
In vivo studies

Vandetanib inhibits 8305 C tumor growth in mice with no body weight loss. Thirty days after subcutaneous xenotransplantation of $8305 \mathrm{C}$ cells in CD $n u / n u$ mice, tumor masses reached the average volume of $100 \mathrm{~mm}^{3}$ and treatment with vandetanib was initiated. In order to establish the optimal antitumor dose, two different doses were administered. At the lower dose of $12.5 \mathrm{mg} / \mathrm{kg}$ a slight, but not significant, antitumor activity was recorded (overall from days 16 to 22), and no statistical differences were obtained when tumor volumes in the treatment group were compared to the control group (Fig. 6A). 

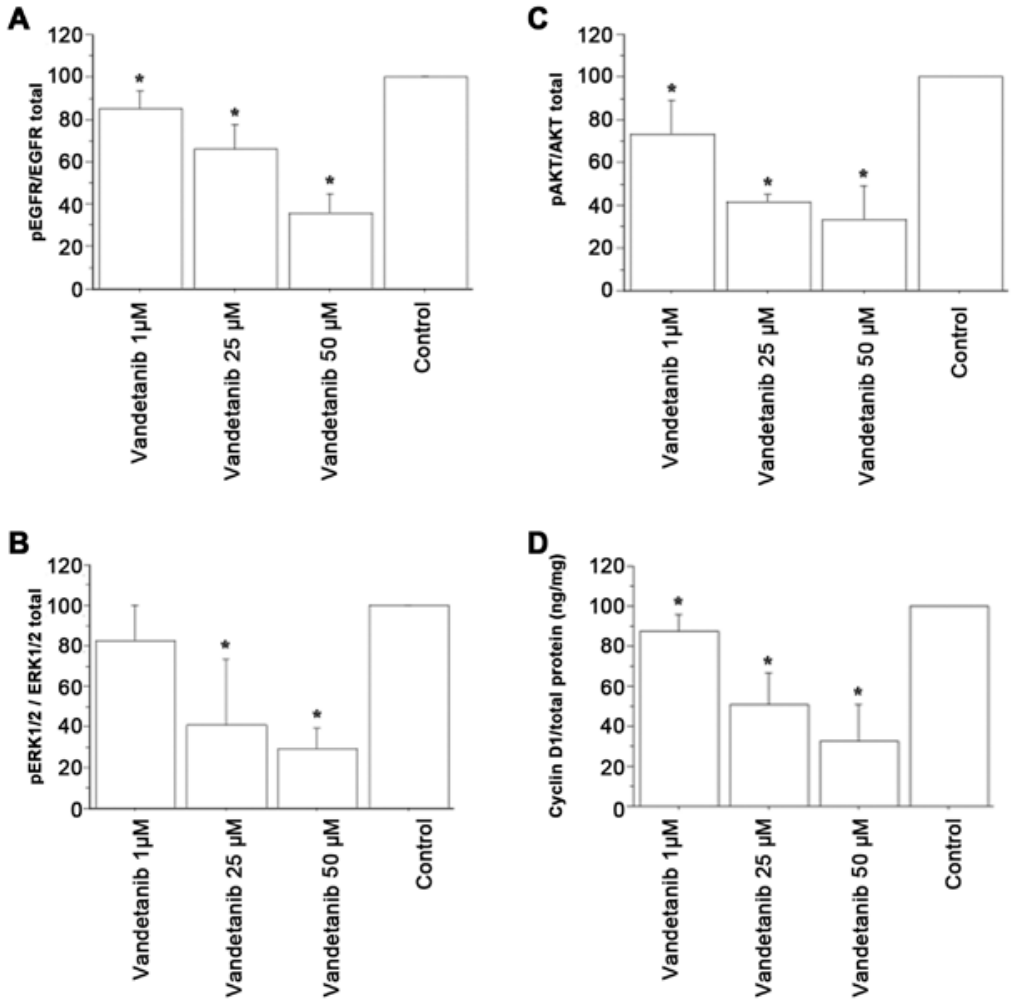

Figure 4. Inhibition of epidermal growth factor receptor (EGFR), AKT, ERK1/2 phosphorylation, or cyclin D1 protein expression in anaplastic thyroid cancer (ATC) cells. (A) Inhibition of EGFR phosphorylation by vandetanib in ATC cells after $72 \mathrm{~h}$ of treatment. Experiments were repeated thrice, with eight samples (for each dose). Mean $( \pm \mathrm{SE}) ;{ }^{*} \mathrm{P}<0.05$ vs. control. (B and C) Inhibition of ERK1/2 (pThr185/pTyr187) and AKT (pThr308) phosphorylation by vandetanib in ATC cells after $72 \mathrm{~h}$ of treatment. Experiments were repeated, independently, thrice with eight samples (for each dose). Mean ( \pm SE); ${ }^{\text {"P }}<0.05$ vs. control. (D) Cyclin D1 concentrations in ATC cells exposed to vandetanib or vehicle for $72 \mathrm{~h}$. Cyclin D1 results are expressed as ng/mg of total protein. Experiments were repeated 6 times with eight samples (for each dose). Mean $( \pm \mathrm{SE}) ;{ }^{*} \mathrm{P}<0.05$ vs. control.
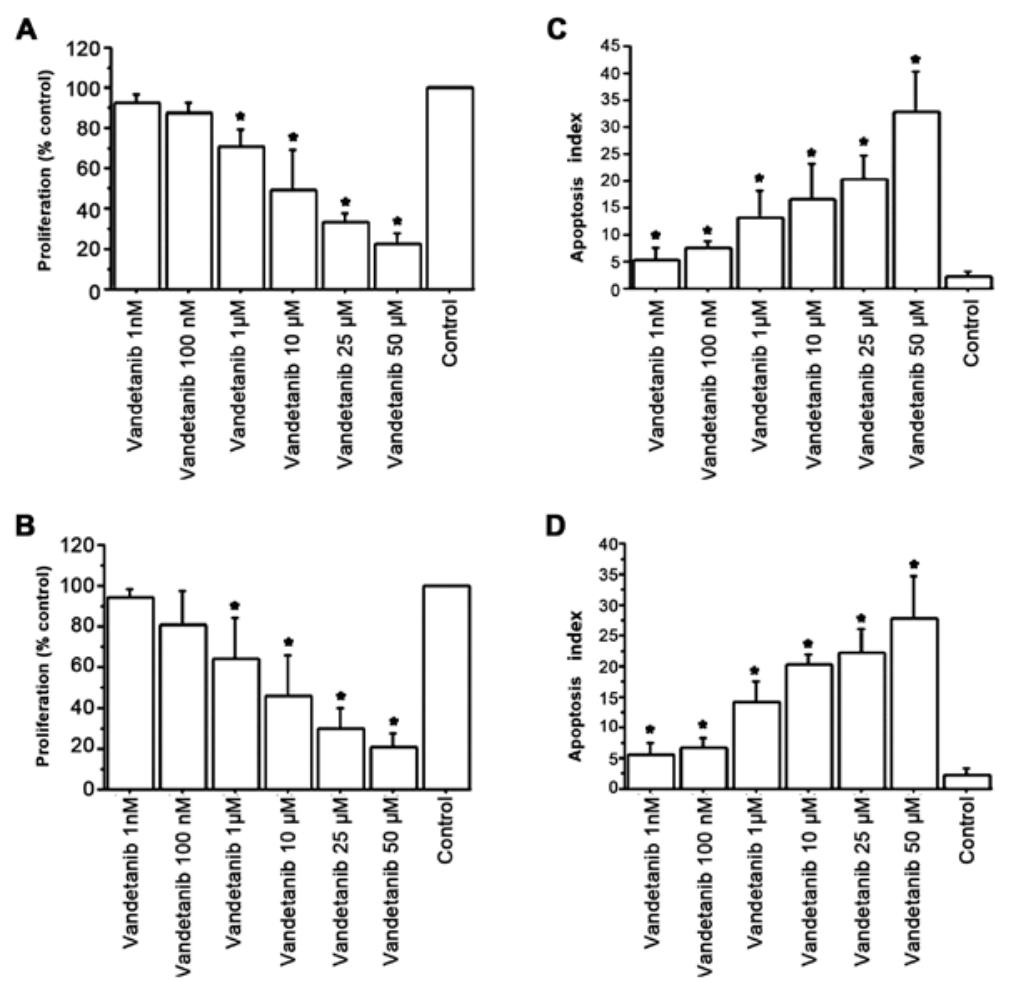

Figure 5. WST-1 and apoptosis assays in 8305C or AF cells. WST-1 assay results in (A) 8305C and (B) AF cells treated with vandetanib for $24 \mathrm{~h}$. A significant inhibition of proliferation vs. control is shown with vandetanib. Bars are mean $( \pm \mathrm{SD}){ }^{*} \mathrm{P}<0.05$ vs. control with Bonferroni-Dunn test. Apoptosis in (C) $8305 \mathrm{C}$ or (D) $\mathrm{AF}$ cells exposed to vandetanib for $48 \mathrm{~h}$ [mean $( \pm \mathrm{SD})$ of the samples]. Apoptosis index (ratio between apoptotic and total cells) x100 was determined by Hoechst staining. One-way ANOVA was used to analyze the data (with Newman-Keuls multiple comparisons test, and with a test for linear trend) ( $\mathrm{P}<0.001$ vs. control). $\mathrm{IC}_{50}$ vs. controls were estimated by non-linear regression fit (see Results); $\mathrm{IC}_{50}$ was $9.6 \pm 3.4 \mu \mathrm{M}$ for $8305 \mathrm{C}$ cells, and $4.7 \pm 1.8 \mu \mathrm{M}$ in $\mathrm{AF}$ cells. 

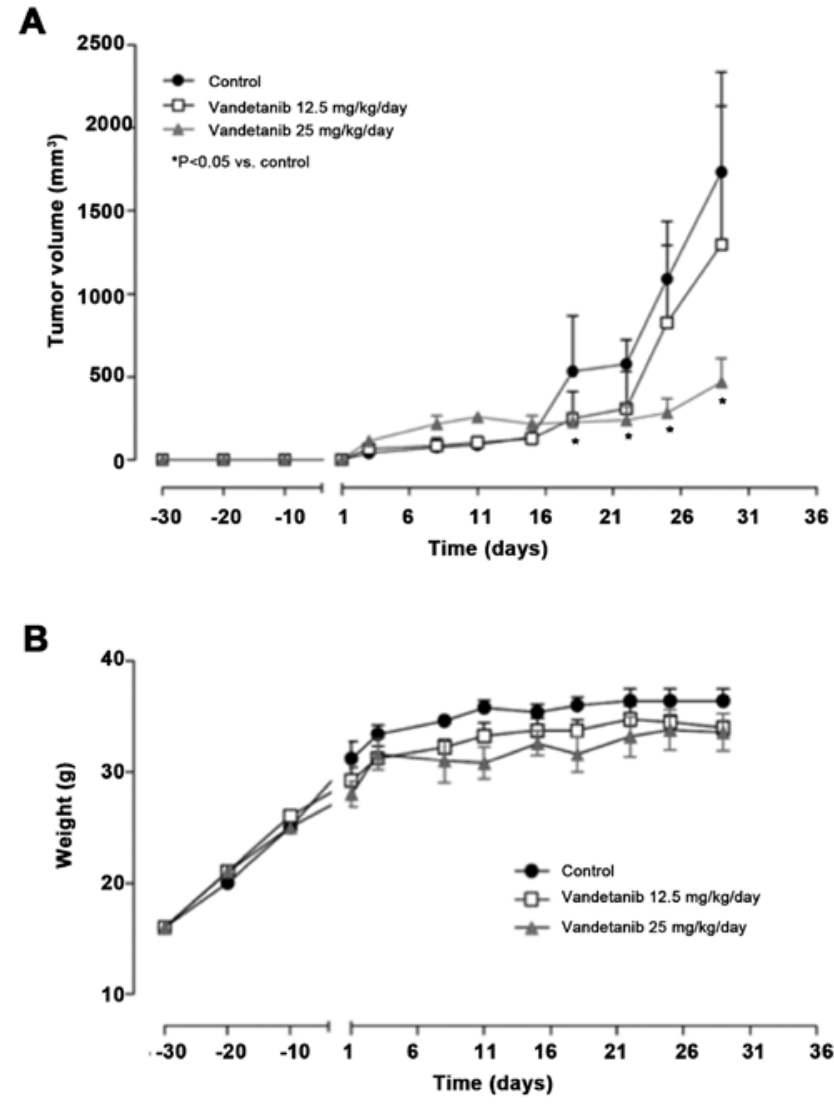

Figure 6. In vivo experiments. (A) Dose-dependent antitumor in vivo effect of vandetanib at the dose of 12.5 and $25 \mathrm{mg} / \mathrm{kg} /$ day intraperitoneally (i.p.), on $8305 \mathrm{C}$ tumors xenotransplanted in CD $n u / n u$ mice. (B) Weights of mice monitored during the treatment with the two doses of the drug and vehicle alone. Symbols and bars, mean $( \pm \mathrm{SE}) ;{ }^{*} \mathrm{P}<0.05$ vs. vehicle-treated controls.

In contrast, at the highest dose of $25 \mathrm{mg} / \mathrm{kg} /$ day i.p., vandetanib significantly inhibited tumor growth (e.g., at day 25, 282.1 vs. $1,086.9 \mathrm{~mm}^{3}$ of controls $\mathrm{P}<0.05$; Fig. 6A). Notably, no loss of mouse body weight throughout the course of the experiment was observed at both the administered doses, suggesting that the vandetanib treatment was well tolerated even at its optimal antitumor dose (Fig. 6B).

Vandetanib decreases VEGF-A expression and microvessel density in $8305 \mathrm{C}$ tumor tissues. 8305C cells led to the formation of a tumor histologically similar to ATC. Vandetanib significantly reduced VEGF-A and FVIII immunostaining. A localized immunoreactivity for VEGF-A was present in cells of the control cancer mass, and vandetanib reduced it $(51 \pm 9$ vs. $37 \pm 7 ; \mathrm{P}<0.05)$, with a concurrent reduction in microvessel density ( $15 \pm 4$ vs. controls $26 \pm 7$; $\mathrm{P}<0.05)$.

\section{Discussion}

Vandetanib belongs to the TKIs, that are under evaluation for ATC treatment (26).

With the present study, we contributed to the understanding of the anticancer activity of vandetanib, demonstrating that: i) it inhibited primary ATC cell proliferation in vitro, through increased apoptosis, and suppressed the migration and invasion abilities as well; and ii) it blocked $8305 \mathrm{C}$ cell proliferation in vitro, increasing apoptosis and reducing $8305 \mathrm{C}$ tumor growth in CD nu/nu mice as well, with no toxicity.

Our results are in line with those of another study that reported how vandetanib is able to inhibit $8305 \mathrm{C}$ cell growth in vivo, and to block angiogenesis, decreasing vascular permeability (27). We also observed the important antiangiogenic activity of vandetanib in $8305 \mathrm{C}$ xenotransplants.

The antiproliferative action of vandetanib was observed in all the used primary ATC cells, independently from the absence/presence of ${ }^{\mathrm{V} 600 \mathrm{E}} B R A F$ mutation.

Our data support the concept that vandetanib could be used for a multiple signal inhibition (involving RET, VEGFR, EGFR, ERK, AKT, and others), and it also exhibits antiangiogenic activity (28).

It is suggested that AKT plays a crucial role in ATC oncogenesis, and it has been demonstrated that pharmacological and molecular inhibition of PI3K or AKT isoforms are able to reduce the in vitro growth and motility of human TC cell lines (29,30). Moreover, both RAS/RAF/MAPK, ERK and PI3K pathways are implicated in the carcinogenesis of TCs, and mutations in such genes have been reported in ATC (31). Since AKT and ERK proteins are activated, once phosphorylated, in ATC, these proteins have been suggested as potential targets of therapy. In the present study in ATC cells, vandetanib significantly inhibited ERK1/2 and AKT phosphorylation.

Furthermore, EGFR phosphorylation in ATC cells was significantly reduced by vandetanib treatment, according to the results obtained by Di Desidero et al (32) and our previous results (33), reporting that TKI suppressed EGFR phosphorylation in ATC.

Cyclin D1 regulates cell cycle progression (34), and its expression was observed at different levels in $\sim 67 \%$ of ATC cells by Lee et al (35). In addition, overexpression of cyclin D1 was reported in $77 \%$ of ATC by Wiseman et al (36). Vandetanib, a TKI of both VEGFR-2, and EGFR, inhibited cell growth downregulating cyclin E and D1 expression (37). Notably, we showed that vandetanib downregulated the cyclin D1 protein in ATC cells.

We found a significant $8305 \mathrm{C}$ cell-derived tumor growth inhibition in CD $n u / n u$ mice by vandetanib, without body weight loss, suggesting a minimal toxicity profile, whereas other compounds are known to provoke different adverse effects in humans and animals (38). Nevertheless, we did not collect data concerning the kidney, liver, or other biochemical tests, that will be provided in future studies.

Antineoplastic activity of vandetanib in ATC is the result of different effects on tumoral cells, that include: i) antiproliferative activity; ii) increased apoptosis; iii) inhibition of both migration, and invasion; and iv) inhibition of cancer neovascularization.

New therapeutic attempts for the treatment of ATC are ongoing, even if various limitations are still present for the selective use of new molecules. Even if neoplastic tissue has a potential target (as BRAF), the tumor response is present in only a few patients. As we achieve target inhibition, any response may occur owing to the increased activity of other compensatory pathways, that rescue cancer cell growth. The efficacy of treatment could be increased by assessing the sensitivity of primary ATC cells from each subject to different TKIs. In fact, in vitro chemosensitivity tests are able to predict 
in vivo effectiveness in $60 \%$ of cases (39), while a negative chemosensitivity test in vitro is associated with a $90 \%$ of ineffectiveness of the treatment in vivo $(39,40)$, thus avoiding the administration of inactive chemotherapeutics to these patients $(15,16,24,26)$.

In the present study, we first showed an antitumoral activity of vandetanib (a multi-targeted kinase inhibitor, with antiangiogenic effect) in human primary ATC cell cultures established directly from patients, paving the way for personalized TKI and for future clinical trials.

\section{Acknowledgements}

Not applicable.

\section{Funding}

GB was supported by a grant from the Associazione Italiana per la Ricerca sul Cancro (IG-17672).

\section{Availability of data and materials}

All data generated or analyzed during this study are included in this published article.

\section{Authors' contributions}

SMF, GB, PM, AA and PF made substantial contributions to conception and design, and to the acquisition of data; TDD, IR, GE, FR, AF, PO, SRP, AP, SP, CLM, SU, EB and GM analysed the data; SMF, GB, TDD, AA and PF have been involved in drafting the manuscript; AA revised it critically for important intellectual content. All authors read and approved the manuscript and agree to be accountable for all aspects of the research in ensuring that the accuracy or integrity of any part of the study are appropriately investigated and resolved. All authors read and approved the final manuscript.

\section{Ethics approval and consent to participate}

All patients and controls agreed to enter the study, which was approved by the local Ethics Committee of the University of Pisa (see Materials and methods section).

\section{Consent for publication}

Not applicable.

\section{Competing interests}

The authors declare no competing interests.

\section{References}

1. Hundahl SA, Fleming ID, Fremgen AM and Menck HR: A National Cancer Data Base report on 53,856 cases of thyroid carcinoma treated in the U.S., 1985-1995 [see comments]. Cancer 83: 2638-2648, 1998.

2. Kitamura Y, Shimizu K, Nagahama M, Sugino K, Ozaki O, Mimura T, Ito K, Ito K and Tanaka S: Immediate causes of death in thyroid carcinoma: Clinicopathological analysis of 161 fatal cases. J Clin Endocrinol Metab 84: 4043-4049, 1999.
3. Greene FL, Page DL, Fleming ID, Fritz AG, Balch CM Haller DG and Morrow M (eds): Thyroid. In: American Joint Committee on Cancer: AJCC Cancer Staging Manual. 6th edition. Springer-Verlag, New York, NY, p77, 2002.

4. Miccoli P, Materazzi G, Antonelli A, Panicucci E, Frustaci G and Berti P: New trends in the treatment of undifferentiated carcinomas of the thyroid. Langenbecks Arch Surg 392: 397-404, 2007.

5. Kebebew E: Anaplastic thyroid cancer: Rare, fatal, and neglected. Surgery 152: 1088-1089, 2012.

6. De Crevoisier R, Baudin E, Bachelot A, Leboulleux S, Travagli JP, Caillou B and Schlumberger M: Combined treatment of anaplastic thyroid carcinoma with surgery, chemotherapy, and hyperfractionated accelerated external radiotherapy. Int J Radiat Oncol Biol Phys 60: 1137-1143, 2004.

7. Smallridge RC, Ain KB, Asa SL, Bible KC, Brierley JD, Burman KD, Kebebew E, Lee NY, Nikiforov YE, Rosenthal MS, et al; American Thyroid Association Anaplastic Thyroid Cancer Guidelines Taskforce: American Thyroid Association guidelines for management of patients with anaplastic thyroid cancer. Thyroid 22: 1104-1139, 2012.

8. Antonelli A, Fallahi P, Ferrari SM, Ruffilli I, Santini F, Minuto M, Galleri D and Miccoli P: New targeted therapies for thyroid cancer. Curr Genomics 12: 626-631, 2011.

9. Jasim S, Ozsari L and Habra MA: Multikinase inhibitors use in differentiated thyroid carcinoma. Biologics 8: 281-291, 2014.

10. Johanson V, Ahlman H, Bernhardt P, Jansson S, Kölby L, Persson F, Stenman G, Swärd C, Wängberg B, Stridsberg M, et al: A transplantable human medullary thyroid carcinoma as a model for RET tyrosine kinase-driven tumorigenesis. Endocr Relat Cancer 14: 433-444, 2007.

11. Wells SA Jr, Robinson BG, Gagel RF, Dralle H, Fagin JA, Santoro M, Baudin E, Elisei R, Jarzab B, Vasselli JR, et al: Vandetanib in patients with locally advanced or metastatic medullary thyroid cancer: A randomized, double-blind phase III trial. J Clin Oncol 30: 134-141, 2012.

12. Cooper MR, Yi SY, Alghamdi W, Shaheen DJ and Steinberg M: Vandetanib for the treatment of medullary thyroid carcinoma. Ann Pharmacother 48: 387-394, 2014.

13. Leboulleux S, Bastholt L, Krause T, de la Fouchardiere C, Tennvall J, Awada A, Gómez JM, Bonichon F, Leenhardt L, Soufflet C, et al: Vandetanib in locally advanced or metastatic differentiated thyroid cancer: A randomised, double-blind, phase 2 trial. Lancet Oncol 13: 897-905, 2012.

14. AstraZeneca. Evaluation of Efficacy, Safety of Vandetanib in Patients With Differentiated Thyroid Cancer (VERIFY) [ClinicalTrials.gov Identifier: NCT01876784]. 2016. Available from: https://www.clinicaltrials.gov/ct2/show/NCT01876784. Last Update Posted: September 6, 2017.

15. Antonelli A, Ferrari SM, Fallahi P, Berti P, Materazzi G, Barani L, Marchetti I, Ferrannini E and Miccoli P: Primary cell cultures from anaplastic thyroid cancer obtained by fine-needle aspiration used for chemosensitivity tests. Clin Endocrinol (Oxf) 69: 148-152, 2008.

16. Antonelli A, Ferrari SM, Fallahi P, Berti P, Materazzi G, Marchetti I, Ugolini C, Basolo F, Miccoli P and Ferrannini E: Evaluation of the sensitivity to chemotherapeutics or thiazolidinediones of primary anaplastic thyroid cancer cells obtained by fine-needle aspiration. Eur J Endocrinol 159: 283-291, 2008.

17. Antonelli A, Ferrari SM, Fallahi P, Berti P, Materazzi G, Minuto M, Giannini R, Marchetti I, Barani L, Basolo F, et al: Thiazolidinediones and antiblastics in primary human anaplastic thyroid cancer cells. Clin Endocrinol (Oxf) 70: 946-953, 2009.

18. Fiore L, Pollina LE, Fontanini G, Casalone R, Berlingieri MT, Giannini R,Pacini F, Miccoli P, Toniolo A,Fusco A, et al: Cytokine production by a new undifferentiated human thyroid carcinoma cell line, FB-1. J Clin Endocrinol Metab 82: 4094-4100, 1997.

19. Agretti P, De Marco G, De Servi M, Marcocci C, Vitti P, Pinchera A and Tonacchera M: Evidence for protein and mRNA TSHr expression in fibroblasts from patients with thyroid-associated ophthalmopathy (TAO) after adipocytic differentiation. Eur J Endocrinol 152: 777-784, 2005.

20. Copland JA, Marlow LA, Williams SF, Grebe SK, Gumz ML, Maples WJ, Silverman VE and Smallridge RC: Molecular diagnosis of a BRAF papillary thyroid carcinoma with multiple chromosome abnormalities and rare adrenal and hypothalamic metastases. Thyroid 16: 1293-1302, 2006.

21. Christensen L, Blichert-Toft M, Brandt M, Lange M, Sneppen SB, Ravnsbaek J, Mollerup CL, Strange L, Jensen F, Kirkegaard J, et al: Thyroperoxidase (TPO) immunostaining of the solitary cold thyroid nodule. Clin Endocrinol (Oxf) 53: 161-169, 2000. 
22. Antonelli A, Ferrari SM, Fallahi P, Frascerra S, Piaggi S, Gelmini S, Lupi C, Minuto M, Berti P, Benvenga S, et al: Dysregulation of secretion of CXC alpha-chemokine CXCL10 in papillary thyroid cancer: Modulation by peroxisome proliferator-activated receptor-gamma agonists. Endocr Relat Cancer 16: 1299-1311, 2009.

23. Antonelli A, Bocci G, La Motta C, Ferrari SM, Fallahi P, Fioravanti A, Sartini S, Minuto M, Piaggi S, Corti A, et al: Novel pyrazolopyrimidine derivatives as tyrosine kinase inhibitors with antitumoral activity in vitro and in vivo in papillary dedifferentiated thyroid cancer. J Clin Endocrinol Metab 96: E288-E296, 2011.

24. Antonelli A, Bocci G, La Motta C, Ferrari SM, Fallahi P, Ruffilli I, Di Domenicantonio A, Fioravanti A, Sartini S, Minuto M, et al: CLM94, a novel cyclic amide with anti-VEGFR-2 and antiangiogenic properties, is active against primary anaplastic thyroid cancer in vitro and in vivo. J Clin Endocrinol Metab 97: E528-E536, 2012.

25. Bocci G, Fioravanti A, La Motta C, Orlandi P, Canu B, Di Desidero T, Mugnaini L, Sartini S, Cosconati S, Frati R, et al: Antiproliferative and proapoptotic activity of CLM3, a novel multiple tyrosine kinase inhibitor, alone and in combination with SN-38 on endothelial and cancer cells. Biochem Pharmacol 81: 1309-1316, 2011.

26. Antonelli A, Fallahi P, Ulisse S, Ferrari SM, Minuto M Saraceno G, Santini F, Mazzi V, D'Armiento M and Miccoli P: New targeted therapies for anaplastic thyroid cancer. Anticancer Agents Med Chem 12: 87-93, 2012.

27. Gule MK, Chen Y, Sano D, Frederick MJ, Zhou G, Zhao M, Milas ZL, Galer CE, Henderson YC, Jasser SA, et al: Targeted therapy of VEGFR2 and EGFR significantly inhibits growth of anaplastic thyroid cancer in an orthotopic murine model. Clin Cancer Res 17: 2281-2291, 2011.

28. La Motta C, Mugnaini L, Sartini S, Da Settimo F, Bocci G, Fioravanti A, Del Tacca M and Martini C: 2007 Derivati a nucleo pirazolo $(3,4-\mathrm{d})$ pirimidinico quali inibitori di proteina tirosina chinasi. RM2007A000480 del 14/9/2007

29. Liu Z, Hou P, Ji M, Guan H, Studeman K, Jensen K, Vasko V, El-Naggar AK and Xing M: Highly prevalent genetic alterations in receptor tyrosine kinases and phosphatidylinositol 3-kinase/akt and mitogen-activated protein kinase pathways in anaplastic and follicular thyroid cancers. J Clin Endocrinol Metab 93: 3106-3116, 2008.

30. Shinohara M, Chung YJ, Saji M and Ringel MD: AKT in thyroid tumorigenesis and progression. Endocrinology 148: 942-947, 2007.
31. Santarpia L, El-Naggar AK, Cote GJ, Myers JN and Sherman SI Phosphatidylinositol 3-kinase/akt and ras/raf-mitogen-activated protein kinase pathway mutations in anaplastic thyroid cancer. J Clin Endocrinol Metab 93: 278-284, 2008.

32. Di Desidero T, Fioravanti A, Orlandi P, Canu B, Giannini R, Borrelli N, Man S, Xu P, Fontanini G, Basolo F, et al: Antiproliferative and proapoptotic activity of sunitinib on endothelial and anaplastic thyroid cancer cells via inhibition of Akt and ERK1/2 phosphorylation and by down-regulation of cyclin-D1. J Clin Endocrinol Metab 98: E1465-E1473, 2013

33. Antonelli A, Bocci G, Fallahi P, La Motta C, Ferrari SM, Mancusi C, Fioravanti A, Di Desidero T, Sartini S, Corti A, et al: CLM3, a multitarget tyrosine kinase inhibitor with antiangiogenic properties, is active against primary anaplastic thyroid cancer in vitro and in vivo. J Clin Endocrinol Metab 99: E572-E581, 2014.

34. Klein EA and Assoian RK: Transcriptional regulation of the cyclin D1 gene at a glance. J Cell Sci 121: 3853-3857, 2008

35. Lee JJ, Au AY, Foukakis T, Barbaro M, Kiss N, Clifton-Bligh R, Staaf J, Borg A, Delbridge L, Robinson BG, et al: Array-CGH identifies cyclin D1 and UBCH10 amplicons in anaplastic thyroid carcinoma. Endocr Relat Cancer 15: 801-815, 2008.

36. Wiseman SM, Masoudi H, Niblock P, Turbin D, Rajput A, Hay J, Bugis S, Filipenko D, Huntsman D and Gilks B: Anaplastic thyroid carcinoma: Expression profile of targets for therapy offers new insights for disease treatment. Ann Surg Oncol 14: 719-729, 2007.

37. Sarkar S, Mazumdar A, Dash R, Sarkar D, Fisher PB and Mandal M: ZD6474, a dual tyrosine kinase inhibitor of EGFR and VEGFR-2, inhibits MAPK/ERK and AKT/PI3-K and induces apoptosis in breast cancer cells. Cancer Biol Ther 9: 592-603, 2010.

38. Ye L, Santarpia L and Gagel RF: The evolving field of tyrosine kinase inhibitors in the treatment of endocrine tumors. Endocr Rev 31: 578-599, 2010.

39. Blumenthal RD and Goldenberg DM: Methods and goals for the use of in vitro and in vivo chemosensitivity testing. Mol Biotechnol 35: 185-197, 2007.

40. Antonelli A, Ferri C, Ferrari SM, Sebastiani M, Colaci M, Ruffilli I and Fallahi P: New targeted molecular therapies for dedifferentiated thyroid cancer. J Oncol 2010: 921682, 2010. 